\title{
The oocyte and its role in regulating ovulation rate: a new paradigm in reproductive biology
}

\author{
K P McNatty, L G Moore, N L Hudson, L D Quirke, S B Lawrence, K Reader, J P Hanrahan ${ }^{1}$, \\ P Smith, N P Groome ${ }^{2}, M$ Laitinen ${ }^{3}$, O Ritvos ${ }^{3}$ and J L Juengel \\ AgResearch, Wallaceville Animal Research Centre, PO Box 40063, Upper Hutt, New Zealand, ${ }^{1}$ Teagasc, \\ Athenry Research Centre, Athenry, Ireland, ${ }^{2}$ School of BMS, Oxford Brookes University, Gipsy Lane, Headington, \\ Oxford X3 OBP, UK and ${ }^{3}$ Biomedicum Helsinki, PO Box 63 (Haartmaninkatu 8), FIN-00014, University of \\ Helsinki, Helsinki, Finland \\ Correspondence should be addressed to Ken P McNatty; Email: ken.mcnatty@agresearch.co.nz
}

\begin{abstract}
Ovulation rate in mammals is determined by a complex exchange of hormonal signals between the pituitary gland and the ovary and by a localised exchange of hormones within ovarian follicles between the oocyte and its adjacent somatic cells. From examination of inherited patterns of ovulation rate in sheep, point mutations have been identified in two oocyteexpressed genes, BMP15 (GDF9B) and GDF9. Animals heterozygous for any of these mutations have higher ovulation rates (that is, + 0.8-3) than wild-type contemporaries, whereas those homozygous for each of these mutations are sterile with ovarian follicular development disrupted during the preantral growth stages. Both GDF9 and BMP15 proteins are present in follicular fluid, indicating that they are secreted products. In vitro studies show that granulosa and/or cumulus cells are an important target for both growth factors. Multiple immunisations of sheep with BMP15 or GDF9 peptide protein conjugates show that both growth factors are essential for normal follicular growth and the maturation of preovulatory follicles. Shortterm (that is, primary and booster) immunisation with a GDF9 or BMP15 peptide-protein conjugate has been shown to enhance ovulation rate and lamb production. In summary, recent studies of genetic mutations in sheep highlight the importance of oocyte-secreted factors in regulating ovulation rate, and these discoveries may help to explain why some mammals have a predisposition to produce two or more offspring rather than one.

Reproduction (2004) 128 379-386
\end{abstract}

\section{Introduction}

Ovulation rate in mammals is determined by a complex exchange of hormone signals between the pituitary gland and the ovary, and by a localised exchange of hormones within ovarian follicles between the oocyte and its adjacent somatic cells (Dong et al. 1996, Galloway et al. 2000, Eppig 2001, Richards 2001, Findlay 2003).

From examination of inherited patterns of ovulation rate in sheep, several breeds have been identified with mutations in two growth factor genes that are expressed in oocytes, namely, bone morphogenetic protein 15 (BMP15), also known as growth differentiation factor 9B (GDF9B), and GDF9 (see McNatty et al. 2003 for review). BMP15 and GDF9 are two closely related members of the transforming growth factor- $\beta$ (TGF $\beta$ ) superfamily, many of which are important for regulating ovarian follicular development (Chang et al. 2002, Knight \& Glister 2003, Lin et al. 2003, Shimasaki et al. 2004). However, what distinguishes BMP15 and GDF9 from other TGF $\beta$ superfamily members is that changing concentrations of these two factors in vivo leads to incremental changes in ovulation rate in sheep (Galloway et al. 2000, Juengel et al. 2002, 2003, McNatty et al. 2003, Hanrahan et al. 2004). The significance of these discoveries is that the oocyte appears to regulate the growth and differentiation of adjacent somatic cells as well as their responsiveness to endocrine signals and thereby the number of follicles that mature and ovulate.

The purpose of this review is to summarise recent results showing that BMP15 and GDF9 are important factors regulating ovulation rate. Particular emphasis will be placed on the BMP15 and GDF9 mutations and physiological results arising from studies in sheep.

\section{Some functional and structural properties of BMP15 and GDF9}

Within the ovary, both BMP15 and GDF9 mRNA and protein are localised exclusively to the oocyte. The only 
exception to this is that GDF9 mRNA and protein have been localised to granulosa cells immediately adjacent to the oocyte in some primates (Sidis et al. 1998, Duffy 2003). It is also worth noting that BMP15 and GDF9 mRNA have been identified in the pituitary glands and testes of some species, albeit in limited amounts (Fitzpatrick et al. 1998, Otsuka \& Shimasaki 2002), suggesting that these factors have some regulatory roles in other tissues.

In sheep, BMP15 mRNA and protein are not present until follicles have just begun to grow (that is, the primary stage of development): thereafter, BMP15 is localised to oocytes of most, if not all, developing follicles (Galloway et al. 2000, Juengel et al. 2002). GDF9 mRNA and protein can be identified in sheep oocytes during follicular formation, in primordial (type 1) follicles and in oocytes at all stages of follicular growth (Bodensteiner et al. 1999, Juengel et al. 2002, Mandon-Pepin et al. 2003). Under in vitro conditions, GDF9 protein is present in both normallooking and degenerating ovine oocytes, and even in highly disorganised follicular structures, indicating that its distribution is widespread in oocytes notwithstanding the functional status of its surrounding somatic cells (unpublished data). There are species differences with respect to the ontogeny of expression of both BMP15 and GDF9 during follicular development (Aaltonen et al. 1999, Bodensteiner et al. 1999, Eckery et al. 2002, Erickson \& Shimasaki 2003).

Like other TGF $\beta$ superfamily members, BMP15 and GDF9 are translated as preproproteins composed of a signal peptide, a large proregion and a smaller mature region (Flg. 1). After removal of the signal peptide, further intracellular processing results in the separation of the biologically active mature region from the proregion (Kingsley 1994). Under reducing conditions, both the mature and unprocessed promature forms of BMP15 and GDF9 can be identified in follicular fluid from sheep (unpublished data), and it remains to be determined what are the final forms of these proteins that regulate target cell functions. Normally, the biologically active form of a TGF $\beta$ superfamily member is a covalently linked homo- or heterodimer (Fig. 1). However, BMP15 and GDF9 lack the fourth

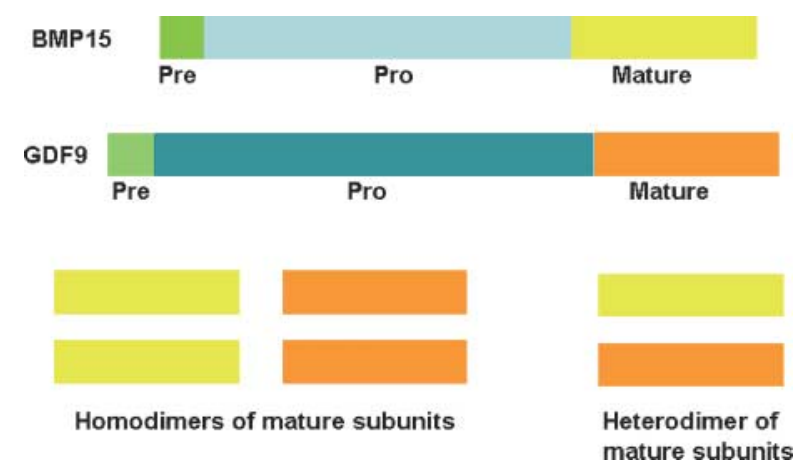

Figure 1 Schematic outline of the BMP15 and GDF9 molecules.

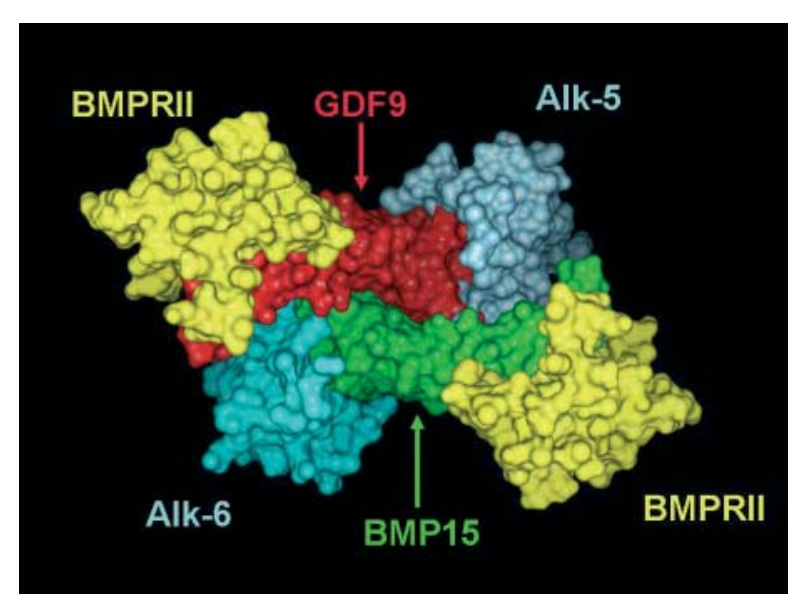

Figure 2 Molecular surface representation of a putative heterodimer (BMP15/GDF9) bound to the extracellular domains of two type I receptors (ALK5) and two type II receptors (BMPRII). Arrows indicate the BMP15 (green) and GDF9 (red) molecules, whereas ALK5 and ALK6 are coloured light and dark blue respectively and BMPRII coloured yellow. The non-covalently linked GDF9 and BMP15 molecules can be compared with the palms of each hand in contact with one another, and the BMPRII receptors attached to the knuckles and the ALK5 and ALK6 receptors to the fingertips.

of the normally conserved seven cysteines that are required for the intersubunit disulphide bridge (McPherron \& Lee 1993, Laitinen et al. 1998). In vitro studies using cell expression systems indicate that both BMP15 and GDF9 can be expressed into media as non-covalently linked homodimers, or coexpressed as heterodimers (Liao et al. 2003).

The interaction of BMP15 or GDF9 with the target cell is thought to be via two types of membrane-bound serine/ threonine kinases, of which there are seven type I receptors (ALK1-7) and five known mammalian type II receptors (Act R-II, Act R-IIB, AMHR-II, BMPR-II and TGFßR-II). BMP15 is reported to bind to a BMP type I receptor (ALK6) and to BMPR-II (Moore et al. 2003), whereas GDF9 is reported to bind to a TGF $\beta$ type 1 receptor (ALK-5) (Mazerbourg et al. 2004) and to BMPR-II (Vitt et al. 2002). An example of how a dimeric or heterodimeric BMP15 or GDF9 binds with the extracellular domains of a TGF $\beta$ type I and BMPR-II receptor is shown in Fig. 2. In the sheep ovary, mRNA and protein for ALK5, ALK6 and BMPR-II are observed in both granulosa cells and oocytes of preantral follicles, indicating that both GDF9 and BMP15 are likely to influence early follicular development (Wilson et al. 2001, Souza et al. 2002, unpublished data). The nature of the interactions between homodimers of BMP15 or GDF9 or putative BMP15/GDF9 heterodimers and type I and II receptors are still unresolved, but the downstream signalling pathway involves activation of the Smad proteins (Heldin et al. 1997, Miyazono 2000, Kloos et al. 2002). The effects of BMP15 or GDF9 on follicular cell DNA or steroid synthesis remain to be resolved but appear to differ across species (see Shimasaki et al. (2004) for a recent review). 


\section{BMP15 and GDF9 mutations in sheep and their effects on ovulation rate}

Sheep BMP15 maps to the X chromosome, and the fulllength coding sequence of 1179 nucleotides encodes a preproprotein region of 268 amino-acid residues and a mature protein region of 125 amino-acid residues (Galloway et al. 2000). Sheep GDF9 maps to chromosome 5 (Sadighi et al. 2002), and the full-length coding sequence of 1359 nucleotides encodes a preproprotein region of 318 amino-acid residues and a mature protein region of 135 amino-acid residues (Fig. 1) (Bodensteiner et al. 1999).

Currently, five different point mutations have been identified in the BMP15 gene and one in the GDF9 gene, each having a major effect on ovulation rate (Galloway et al. 2000, Bodin et al. 2003, Hanrahan et al. 2004). These point mutations in BMP15 and GDF9 and the resulting amino-acid changes are summarised in Table 1. All animals heterozygous for any one of these BMP15 or GDF9 mutations have increased ovulation rates, whereas homozygous individuals are sterile with normal ovarian follicular development arrested or abnormal from the type 2 stage of growth (Braw-Tal et al. 1993, Galloway et al. 2000, Bodin et al. 2003, Hanrahan et al. 2004, unpublished data). From in vitro studies, using a cell line expressing recombinant human BMP15 with the Fec $X^{\prime}$ or Fec $X^{B}$ sheep mutation or recombinant human GDF9 with the sheep $\mathrm{FecG}^{\mathrm{H}}$ mutation (Table 1), it was found that the secretion levels of both proteins were significantly lower than those in the wild-types (Liao et al. 2004). Surprisingly, equivalent concentrations of the homozygous mutant forms of BMP15 or GDF9 protein had similar levels of biological activity to that of the wild-type proteins when assessed by a thymidine incorporation assay using rat granulosa cells. The implication of these findings is that sheep with the homozygous mutations $\mathrm{Fec}^{\mathrm{B}}$, $\mathrm{FecG}^{\mathrm{H}}$ or $\mathrm{FecX}^{\mathrm{I}}$ would have biologically active BMP15 or GDF9, although not in sufficient amounts to support ovarian follicular growth since the ovarian phenotypes in these

Table 1 Polymorphic sequence variations in BMP15 and GDF9 that affect ovarian follicular development and ovulation rate in sheep.

\begin{tabular}{lllccl}
\hline Gene & Allele & $\begin{array}{c}\text { Base } \\
\text { change }\end{array}$ & $\begin{array}{c}\text { Coding } \\
\text { residue }(\mathrm{aa})\end{array}$ & $\begin{array}{c}\text { Mature peptide } \\
\text { residue }(\mathrm{aa})\end{array}$ & $\begin{array}{c}\text { Amino-acid } \\
\text { change }\end{array}$ \\
\hline BMP15 & $\mathrm{FecX}^{\mathrm{G}}$ & $\mathrm{C} \rightarrow \mathrm{T}$ & 239 & - & $\mathrm{Gln} \rightarrow \mathrm{STOP}$ \\
& $\mathrm{FecX}^{\mathrm{B}}$ & $\mathrm{G} \rightarrow \mathrm{T}$ & 367 & 99 & $\mathrm{Ser} \rightarrow \mathrm{ll}$ \\
& $\mathrm{FecX}^{\mathrm{l}}$ & $\mathrm{T} \rightarrow \mathrm{A}$ & 299 & 31 & $\mathrm{Val} \rightarrow \mathrm{Asp}$ \\
& $\mathrm{FecX}^{\mathrm{H}}$ & $\mathrm{C} \rightarrow \mathrm{T}$ & 291 & 23 & $\mathrm{Glu} \rightarrow \mathrm{STOP}$ \\
& $\mathrm{FecX}^{\mathrm{L}}$ & $\mathrm{G} \rightarrow \mathrm{A}$ & 321 & 53 & $\mathrm{Cys} \rightarrow \mathrm{Tyr}$ \\
$\mathrm{GDF9}$ & $\mathrm{FecG}^{\mathrm{H}}$ & $\mathrm{C} \rightarrow \mathrm{T}$ & 395 & 77 & Ser $\rightarrow$ Phe \\
\hline
\end{tabular}

Data from Galloway et al. (2000), Bodin et al. (2003) and Hanrahan et al. (2003). For the purposes of this report, the BMP 15 mutation in Lacaune sheep was assigned the allele Fec $\mathrm{X}^{\mathrm{L}}$. This mutation was found as a co-dominant mutation in a Lacaune breed with an autosomal gene. aa $=$ amino acid. animals are similar to those in animals having the Fec $X^{\mathrm{H}}$ or Fec $\mathrm{X}^{\mathrm{G}}$ stop codons and thus, presumably, no biologically active protein.

The mean ovulation rates of F700 Belclare, Cambridge, Hanna and Inverdale ewes heterozygous for the known BMP15 and GDF9 mutations, together with the effects of the mutations on the BMP15 or GDF9 protein or their possible interactions with a type I or II binding domain, are summarised in Table 2. Animals with a likely $50 \%$ reduction in intrafollicular concentrations of BMP15 $\left(F e c X^{\mathrm{G}}\right.$, Fec $X^{\mathrm{H}}$ or Fec $\left.X^{\mathrm{l}}\right)$ have a mean ovulation rate increase of $35-67 \%$, whereas animals heterozygous for a mutation in the region of BMP15 or GDF9 that interacts with a type I or II receptor $\left(\mathrm{FecX}^{\mathrm{B}}\right.$ or $\mathrm{FecG}^{\mathrm{H}}$ ) have mean ovulation rate increases of $87-95 \%$. Of interest are the animals that are heterozygous for mutations in both BMP15 and GDF9 (such as Fec ${ }^{\mathrm{G}}$ and FecG ${ }^{\mathrm{H}}$, and Fec $\mathrm{X}^{\mathrm{B}}$ and $\mathrm{FecG}^{\mathrm{H}}$ ). These animals are likely to have reduced concentrations of BMP15 and possibly an altered interaction between GDF9 and its type I receptor (such as FecX ${ }^{\mathrm{G}}$ and $\mathrm{FecG}^{\mathrm{H}}$ ) or an altered interaction for both BMP15 and GDF9 with their receptor-binding domains $\left(\mathrm{FecX}^{\mathrm{B}}\right.$ and $\mathrm{FecG}^{\mathrm{H}}$ ). The consequence of these double mutations appears to be a synergistic effect on ovulation rate (Table 2). The mean ovulation rates in Lacaune ewes, heterozygous for the BMP15 mutation leading to a tyrosine substituting for a cysteine at mature peptide residue 53 (FecX ${ }^{\mathrm{L}}$; Table 1), is not known, as carrier animals currently identified have another co-dominant mutation on chromosome 11 (Bodin et al. 2003).

The evidence from gene-knockout studies in mice suggests that BMP15 and GDF9 may not affect follicular development and ovulation rate in a similar manner in all species. Female mice lacking a functional GDF9 gene are infertile and have an ovarian phenotype similar to that described for sheep homozygous for the BMP15 $\left(\mathrm{Fec}^{\mathrm{G}}\right.$, Fec $X^{\mathrm{B}}$, Fec $X^{\mathrm{H}}, \mathrm{FecX}^{\mathrm{l}}$ and Fec $\mathrm{X}^{\mathrm{L}}$ ) or the GDF9 mutations $\left(\right.$ FecG $^{\mathrm{H}}$ ) (Table 1) (Braw-Tal et al. 1993, Dong et al. 1996, Galloway et al. 2000, unpublished data). However, mice lacking a functional BMP15 gene have apparently normal follicular development and are fertile, although litter size is reduced by impaired fertilisation of oocytes (Yan et al. 2001). Mice heterozygous for an inactive copy of the BMP15 or GDF9 gene appear to have normal litter sizes, whereas those heterozygous for inactive copies of both a BMP15 and a GDF9 gene have reduced litter sizes: this effect was enhanced in mice without a functional BMP15 gene and heterozygous for an inactive GDF9 gene. In all cases, it seems that follicular growth was normal but that fertilisation of the oocyte was seriously impaired. The reason for the reduced litter size was thought to be inappropriate development of the oocyte-cumulus cell complex, as many oocytes were recovered with few, if any, attached cumulus cells (Yan et al. 2001). 
Table 2 Mean ovulation rate (and percentage increase above WT) in various sheep breeds/lines.

\begin{tabular}{|c|c|c|c|c|c|c|}
\hline $\begin{array}{l}\text { Wild-type, mutation } \\
\text { or immunisation }\end{array}$ & $\begin{array}{l}\text { Predicted effect on BMP15, } \\
\text { GDF9 or receptor type }\end{array}$ & Hanna $^{a}$ & Inverdale $^{\mathrm{a}}$ & F700 Belclare ${ }^{b}$ & Cambridge $^{b}$ & Romney $^{\mathrm{C}}$ (immunised) \\
\hline WT & None & 1.8 & 1.8 & 1.9 & 2.3 & 1.6 \\
\hline $\mathrm{FecX}^{\mathrm{H}}$ (BMP15) & $\begin{array}{l}\text { Reduced concentrations } \\
\text { of mature BMP15 }\end{array}$ & $3.0(+67 \%)$ & - & - & - & - \\
\hline FecX' (BMP15) & $\begin{array}{l}\text { Reduced concentrations } \\
\text { of mature BMP15 }\end{array}$ & - & $2.9(+61 \%)$ & - & - & - \\
\hline Fec $X^{G}(B M P 15)$ & $\begin{array}{l}\text { Reduced concentrations } \\
\text { of mature BMP15 }\end{array}$ & - & - & $2.7(+42 \%)$ & $3.1(+35 \%)$ & - \\
\hline Fec $X^{B}$ (BMP15) & $\begin{array}{l}\text { Disrupted interaction type II } \\
\text { with the receptor-binding domain }\end{array}$ & - & - & $3.7(+95 \%)$ & - & - \\
\hline $\mathrm{FecX}^{\mathrm{H}}$ (GDF9) & $\begin{array}{l}\text { Disrupted interaction with the type I } \\
\text { receptor-binding domain }\end{array}$ & - & - & - & $4.3(+87 \%)$ & - \\
\hline $\mathrm{FecX}^{\mathrm{G}} \& \mathrm{FecG}^{\mathrm{H}}$ & $\begin{array}{l}\text { Reduced concentrations of } \\
\text { mature BMP15 and disrupted } \\
\text { interactions with a type I } \\
\text { receptor-binding domain }\end{array}$ & - & - & - & $5.8(+152 \%)$ & - \\
\hline $\mathrm{FecX}^{\mathrm{B}} \& \mathrm{FecG}^{\mathrm{H}}$ & $\begin{array}{l}\text { Disrupted interactions with the type I } \\
\text { and II receptor-binding domains }\end{array}$ & - & - & $6.1(+221 \%)$ & - & - \\
\hline $\begin{array}{l}\text { Immunised } \\
\text { (BMP15-peptide 2) }\end{array}$ & $\begin{array}{l}\text { Disrupted interaction with a } \\
\text { putative type I } \\
\text { receptor-binding domain }\end{array}$ & - & - & - & - & $2.9(+81 \%)$ \\
\hline $\begin{array}{l}\text { Immunised } \\
\text { (GDF9 peptide 2) }\end{array}$ & $\begin{array}{l}\text { Disrupted interaction with a } \\
\text { putative type I } \\
\text { receptor-binding domain }\end{array}$ & - & - & - & - & $3.5(+121 \%)$ \\
\hline
\end{tabular}

$\mathrm{WT}=$ wild-type animals

${ }^{a}$ Davis et al. 2001.

${ }^{\mathrm{b}}$ Hanrahan et al. 2004.

${ }^{\mathrm{c}}$ Unpublished data.

\section{Regulation of ovulation rate by altering BMP15 and GDF9 concentrations in vivo}

The implication of the ovulation rate outcomes in sheep heterozygous for mutations in either BMP15 or GDF9 is that the absence or extremely low concentrations of either of these factors leads to an inhibition of ovarian follicular development and thus sterility, whereas a partial reduction in concentrations of these factors increases ovulation rate and thus litter size (Davis et al. 2001, Hanrahan et al. 2004). Inverdale ewes heterozygous for the BMP15 mutation (Fec $X^{\prime}$ ) have similar concentrations of plasma follicle-stimulating hormone (FSH) and luteinizing hormone (LH) to their wild-type contemporaries. Moreover, the ovarian secretions of steroids are not different between the heterozygous and wild-type Inverdales, notwithstanding the fact that in heterozygotes the mean ovulation rate is higher and there are more oestrogenic follicles (Shackell et al. 1993). The underlying cause of the higher ovulation rate in heterozygous Inverdales appears to be the precocious maturation of small follicles due to increased $\mathrm{FSH}$ responsiveness and an earlier acquisition of $\mathrm{LH}$ receptors by the granulosa cells (Shackell et al. 1993). This is consistent with the in vitro studies of Otsuka et al. (2001) showing that BMP15 can cause suppression of FSH receptor expression in rat granulosa cells, thereby suggesting that reduced BMP15 concentrations are associated with a higher level of FSH responsiveness. Moreover, the higher ovulation rate in ewes heterozygous for the GDF9 mutation $\mathrm{FecG}^{\mathrm{H}}$ is consistent with at least one report showing that GDF9 inhibits FSH actions in rat granulosa cells in vitro by inhibiting $\mathrm{FSH}$-dependent $\mathrm{LH}$ receptor expression, CAMP production, oestradiol and progesterone synthesis (Vitt et al. 2000).

Since the oocyte is a major source of both BMP15 and GDF9 and the major target for these factors is the granulosa cells (see Shimasaki et al. 2004 for a review), it is reasonable to infer that these oocyte-derived growth factors modulate the responsiveness of granulosa cells to the gonadotrophins. We therefore asked whether the intrafollicular concentrations of BMP15 or GDF9 could be modulated by exogenous means to alter ovulation rate. We have addressed this question, using sheep as our experimental model, and the results from such studies have been very informative.

\section{Long-term immunisations with BMP15 or GDF9 peptides}

In one study, ewes were immunised with either keyhole limpet haemacyanin $(\mathrm{KLH})$ or $\mathrm{KLH}$ conjugated to either a 15 mer BMP15 or a GDF9 peptide sequence from the $\mathrm{N}$-terminal end of each mature protein region (that is, BMP15 peptide 1 or GDF9 peptide 1) (see Juengel et al. 2002). The immunisations, which took place before and during the breeding season, were given i.m. a month apart in Freund's adjuvant for 7 months. Ewes immunised with KLH alone (9/9) maintained regular oestrous cycles of $17 \pm 2$ days during the breeding season. By contrast, most ewes immunised against BMP15 (9/10) or GDF9 (10/10) 
failed to show normal oestrous behaviour throughout the breeding season. Similarly, most of the BMP15- and GDF9-immunised ewes showed no evidence of ovulation or normal patterns of luteal progesterone concentrations. When the ovaries were examined at the end of the experiment (7.5 months after the initial immunisation), it was evident that normal follicular development beyond the type 2 stage of growth did not occur in either the BMP15or GDF9-immunised animals and that the phenotype was similar to that observed in ewes homozygous for mutations in BMP15 or GDF9 (Braw-Tal et al. 1993, Galloway et al. 2000, Hanrahan et al. 2004, unpublished data). As shown by ELISA, ewes immunised against the BMP15 peptide had high antibody titres against ovine (o) BMP15 but showed no cross-reactivity (that is, $<1 \%$ ) to oGDF9. Likewise, ewes immunised with the GDF9 peptide contained antibodies against oGDF9 protein, but not against oBMP15 protein. These data show that secreted forms of both BMP15 and GDF9 are essential for follicular development and ovulation rate in sheep. The aforementioned BMP15 and GDF9 amino-acid sequences (that is, peptide 1) correspond to flexible regions of the respective mature protein regions, and it is not known whether these regions are close to a binding site or a region important for dimerisation. To evaluate the affect of immunising sheep against alternative peptide sequences, we conjugated a 16 mer BMP15 peptide sequence (BMP15, peptide 2) or a 15 mer GDF9 peptide sequence (GDF9, peptide 2), near a putative type 1 receptor-binding region to KLH. Ewes ( $n=9-10$ per group), including a KLH control group, were immunised at monthly intervals in Freund's adjuvant, starting in the non-breeding season and continuing through the breeding season (six monthly injections). The ewes in all treatment groups underwent normal cyclical oestrous activity, and there was no evidence either at laparoscopy (on two separate occasions) or at ovary recovery that any of these treatments caused a reduction in ovarian follicular development. Indeed, the mean \pm S.E.M. ovulation rates were, on most occasions, significantly higher in both the BMP15- and GDF9-treated groups than in the KLH control group (Table 3). When the antibody responses were tested by ELISA, all the BMP15 and GDF9 animals produced antibody responses to BMP15 and GDF9 respectively, but none of the KLH

Table 3 Mean ovulation rates in ewes following long-term immunisation with KLH, KLH-GDF9 peptide 2, or KLH-BMP15 peptide 2 .

\begin{tabular}{lcr}
\hline Treatment & $\begin{array}{c}\text { Mean ovulation } \\
\text { rate }( \pm \text { S.E.M. })\end{array}$ & $\mathbf{N}$ \\
\hline KLH & $1.6 \pm 0.2^{\mathrm{a}}$ & 10 \\
KLH-GDF9 (2) & $3.6 \pm 0.5^{\mathrm{b}}$ & 10 \\
KLH-BMP15 (2) & $3.1 \pm 0.4^{\mathrm{b}}$ & 9 \\
\hline
\end{tabular}

$\mathrm{N}=$ number of ewes. Values with different superscripts are significantly different, $P<0.01$. Unpublished data.

GDF9 peptide 2 and BMP 15 peptide 2 refer to 15 or 16 mer

peptides near a putative BMP type 1 receptor-binding region. control immunised animals produced antibodies to either BMP15 or GDF9. The overall mean ovulation rate increases following the BMP15 (peptide 2) or GDF9 (peptide 2) immunisations were similar to those observed for the heterozygous sheep ( $\mathrm{FecX} \mathrm{X}^{\mathrm{B}}$ and $\mathrm{FecG}^{\mathrm{H}}$ ), where there were mutations in the regions of BMP15 or GDF9 that interact with the type I or II receptors (see Table 2).

\section{Short-term treatments with BMP15 or GDF9 antibodies}

Short-term passive immunisation studies using ovine antiplasma against BMP15 (peptide 1) or GDF9 (peptide 1) indicated that both BMP15 and GDF9 are important for the final phases of follicular maturation (Juengel et al. 2002). This conclusion was based on the following experimental results: four of the five ewes receiving antiplasma against BMP15 failed to ovulate, and three of the five ewes were devoid of surface visible follicles. All ewes $(n=5)$ receiving antiplasma against the GDF9 peptide formed one or two corpora lutea, but three of five ewes displayed abnormal luteal phase patterns of progesterone concentrations. All ewes $(n=4)$ receiving KLH antiplasma ovulated with normal luteal phase patterns of progesterone concentration.

\section{Short-term immunisations with BMP15 or GDF9 peptides}

A number of BMP15 and GDF9 peptide formulations have been tested for their ability to increase ovulation, fertilisation or lambing rates (Juengel et al. 2003, McNatty et al. 2003, unpublished data). The concept being tested is whether it is possible to mimic reliably the lambing and/or ovulation rate increases that are found in ewes that have heterozygous mutations in either BMP15 or GDF9 (Davis et al. 2001, Hanrahan et al. 2003) (Table 1). Using a primary and single booster vaccination with BMP15 (peptide 1) or GDF9 (peptide 1) conjugated to bovine serum albumin (BSA) in a water-based adjuvant, Juengel et al. (2003) reported consistent and significant increases in ovulation rate in ewes immunised with GDF9 peptide $\left(+22 \% ; P<0.05\right.$ ( $\chi_{2}$ analysis); $n=30$ animals) or BMP15 peptide ( $+44 \% ; P<0.05$ ( $\chi_{2}$ analysis); $n=30$ animals) compared with BSA-immunised controls ( $n=50$ animals). Importantly, no adverse affects were observed on fertilisation, embryo survival or ability of ewes to maintain their pregnancy.

A larger study, using BMP15 peptide 1 conjugated to a carrier protein ( $n=94$ animals) or carrier protein alone ( $n=49$ animals) with the same water-based adjuvant as described above (see Juengel et al. 2003), recorded a $25 \%$ increase in both ovulation and lambing rate in the BMP15-immunised group relative to the carrier protein control group (both $P<0.05$ (student's t-test); unpublished data). 


\section{Possible molecular forms of BMP15 and GDF9 in regulating ovulation rate in sheep}

GDF9 and BMP15 potentially could function as homodimers, heterodimers, a combination of the two or some other configuration. We have examined a number of possible relationships between ovulation rate and GDF9 and BMP15 acting as either homodimers or heterodimers. The ovulation rate data considered are those shown in Table 1 for sheep heterozygous for the Fec $X^{\mathrm{I}}, \mathrm{Fec} \mathrm{X}^{\mathrm{H}}, \mathrm{Fec} \mathrm{X}^{\mathrm{G}}, \mathrm{Fec}^{\mathrm{B}}$, $\mathrm{FecG}^{\mathrm{H}}$, Fec $\mathrm{X}^{\mathrm{G}}$ and $\mathrm{FecG}^{\mathrm{H}}$, or Fec $\mathrm{X}^{\mathrm{B}}$ and $\mathrm{FecG}^{\mathrm{H}}$ mutations. The assumptions that were made for GDF9 and BMP15 functioning as homodimers were as follows: (1) the BMP mutations generating stop codons (Fec $X^{H}$ and $F e c X^{G}$ ) (Tables 1 and 2) or the Inverdale (Fec $X^{\prime}$ ) variant of BMP15 (Tables 1 and 2) reduces biological activity at the level of the receptor(s) to 0.5 times that of the wild-type; (2) the mutations in the regions of BMP15 or GDF9 that interact with the type I or II receptors (FecX ${ }^{\mathrm{B}}$ and $\mathrm{FecG}^{\mathrm{H}}$ ) (Tables 1 and 2 ) reduce biological activity at the level of the receptor to 0.25 times that of the wild-type; and (3) mutations in both BMP15 and GDF9 are multiplicative, reducing biological activity at the level at the receptor(s) to 0.125 $\left(\mathrm{FecX}^{\mathrm{G}}\right.$ and $\left.\mathrm{FecG}^{\mathrm{H}} ; 0.5 \times 0.25\right)$ and $0.0625\left(\mathrm{FecX}^{\mathrm{B}}\right.$ and $\left.\mathrm{FecG}^{\mathrm{H}} ; 0.25 \times 0.25\right)$ times that of the wild-types. The assumptions made for Fec $X^{\mathrm{H}}$ or Fec $\mathrm{X}^{\mathrm{G}}$ having only $50 \%$ of normal biological activity was based on the knowledge that these heterozygous animals would have only $50 \%$ of normal concentrations of mature BMP15 because only half of the normal amount of protein could be produced. Animals with the Fec $X^{1}$ mutation were also given the figure of $50 \%$ of normal BMP15 activity on the assumption that the FecX'-produced BMP15 would not dimerise avidly with normal BMP15 protein (Galloway et al. 2000). For the $\mathrm{FecX}^{\mathrm{B}}$ or $\mathrm{FecG}^{\mathrm{H}}$ mutations which require unmutated dimers for normal receptor function, the assumptions were based on the allelic frequency of normal biological activity being $25 \%$ of the wild-type because only $25 \%$ of homodimers in heterozygous animals consist of unmutated proteins. The multiplicative activities were derived from multiplying $\mathrm{FecX}^{\mathrm{G}}$ and $\mathrm{FecG}^{\mathrm{H}}$ (that is, $0.5 \times 0.25$ ) or $\mathrm{FecX}^{\mathrm{B}}$ and FecG ${ }^{\mathrm{H}}$ (that is, $0.25 \times 0.25$ ). Consequently, if BMP15 and GDF9 function as homodimers, the relationship between ovulation rate $(y)$ and theoretical activation level of the receptor $(x)$ as a fraction of the wild-type can be expressed by the equation $y=-77 \operatorname{Ln}(x)+91\left(R^{2}=0.96\right.$; $P<0.001$; regression analysis).

The assumptions made for GDF9 and BMP15 functioning as heterodimers were based on the reasoning outlined above, namely: (1) that the BMP mutations generating stop codons $\left(\mathrm{Fec} \mathrm{X}^{\mathrm{H}}\right.$ and $\mathrm{Fec} \mathrm{X}^{\mathrm{G}}$ ), the Inverdale variant $\left(F e c X^{\prime}\right)$ or those interfering with type I or II receptor binding $\left(\mathrm{Fec} \mathrm{X}^{\mathrm{B}}\right.$ and $\mathrm{FecG}^{\mathrm{H}}$ ) reduce biological activity at the level of the receptor(s) to 0.5 times that of the wild-type; and (2) mutations in two of the above genes are multiplicative, namely, 0.25 times that of the wild-type. The assumptions made for $F e c X^{H}, F_{e c} X^{G}$ and Fec $X^{\prime}$ were the same as those described for the homodimers. For Fec $X^{\mathrm{B}}$ and $\mathrm{FecG}^{\mathrm{H}}$, the assumptions were based on the allelic frequency of normal biological activity being 50\% of the wild-type because $50 \%$ of the heterodimers in heterozygous animals consist of unmutated proteins. With these assumptions, the relationship between ovulation rate (y) and theoretical activation level of the receptor as a fraction of the wild-type $(x)$ can be expressed by the equation $y=146 \operatorname{Ln}(x)+68 \quad\left(R^{2}=0.82 ; \quad P<0.001\right.$; regression analysis).

From these associations, the preferred interpretation is that GDF9 and BMP15 affect follicular development and ovulation rate in sheep as functional homodimers. Verification of this hypothesis will require further in vivo and in vitro testing. It is important to note that the homodimer hypothesis does not exclude the notion of interactions between GDF9 and BMP15 either at the level of receptor or during the post-receptor signalling pathway. Moreover, it does not exclude the possibility that two heterodimers are necessary to activate a type I and II receptor complex.

\section{Conclusion}

Recent studies of genetic mutations in sheep highlight the importance of oocyte-secreted factors in regulating ovarian follicular development and ovulation rate. These findings, together with the immunisation results with BMP15 and GDF9 peptides, demonstrate that by altering the bioavailability of GDF9 and BMP15 in vivo, it is possible by exogenous means to enhance ovulation rate and increase lamb production or to induce infertility. Future studies with GDF9 and/or BMP15 peptides are aimed at translating these findings in sheep to regulating ovulation rate and numbers of offspring in other farmed animals, primates, wildlife or endangered species. The role of oocyte-derived growth factors in either up- or downregulating fertility is an exciting new paradigm in reproduction biology.

\section{Acknowledgements}

This paper was supported by the New Zealand Foundation for Research, Science and Technology; the Royal Society of New Zealand Marsden Fund; and Ovita Limited, Dunedin, New Zealand.

\section{References}

Aaltonen J, Laitinen MP, Vuojolainen K, Jaatinen R, Horelli-Kuitunen N, Seppa L, Louhio H, Tuuri T, Sjoberg J, Butzow R, Hovatta O, Dale L \& Ritvos O 1999 Human growth differentiation factor 9 (GDF-9) and its novel homolog GDF-9B are expected in oocytes during early folliculogenesis. Journal of Clinical Endocrinology and Metabolism $842744-2750$.

Bodensteiner KJ, Clay CM, Moeller CL \& Sawyer HR 1999 Molecular cloning of the ovine growth/differentiation factor-9 gene and 
expression of growth/differentiation factor-9 in ovine and bovine ovaries. Biology of Reproduction 60 381-386.

Bodin L, Lecerf F, Pisselet C, San Cristhal M, Bibe M \& Mulsant P 2003 How many mutations are associated with increased ovulation rate and litter size in progeny of Lacaune meat sheep? Proceedings of the International Workshop on Major Genes and QTL in Sheep and Goat 2-11. Toulouse: INRA.

Braw-Tal R, McNatty KP, Smith P, Heath DA, Hudson NL, Phillips DJ, McLeod BJ \& Davis GH 1993 Ovaries of ewes homozygous for the X-linked Inverdale gene (Fec $\left.X^{\top}\right)$ are devoid of secondary and tertiary follicles but contain many abnormal structures. Biology of Reproduction 49 895-907.

Chang H, Brown CW \& Matzuk MM 2002 Genetic analysis of the mammalian transforming growth factor superfamily. Endocrine Reviews 23 787-823.

Davis GH, Bruce GD \& Dodds KG 2001 Ovulation rate and litter size of prolific Inverdale (Fec $\left.\mathrm{X}^{\mathrm{I}}\right)$ and Hanna $\left(\mathrm{Fec}^{\mathrm{H}}\right)$ sheep. Proceedings of the Association for the Advancement of Animal Breeding and Genetics 14 175-178.

Dong J, Albertini DF, Nishimori K, Rajendra Kumar T, Lu N \& Matzuk MM 1996 Growth differentiation factor-9 is required during early ovarian folliculogenesis. Nature 383 531-535.

Duffy DM 2003 Growth differentiation factor-9 is expressed by the primate follicle through the periovulatory interval. Biology of Reproduction 69 725-732.

Eckery DC, Whale LJ, Lawrence SB, Wylde KA, McNatty KP \& Juengel JL 2002 Expression of mRNA encoding growth differentiation factor 9 and bone morphogenetic protein 15 during follicular formation and growth in a marsupial, the brushtail possum (Trichosurus vulpecula). Molecular and Cellular Endocrinology 192 115-126.

Eppig JJ 2001 Oocyte control of ovarian follicular development and function in mammals. Reproduction 122 829-838.

Erickson GF \& Shimasaki S 2003 The spatiotemporal expression pattern of the bone morphogenetic protein family in rat ovary cell types during the oestrous cycle. Reproductive Biology and Endocrinology 1 1-21.

Findlay JK 2003 Folliculogenesis. In Encyclopaedia of Hormones, vol 1, pp 653-656. Eds HL Henry \& AW Norman. London: Academic Press.

Fitzpatrick SL, Sindoni DM, Shughrue PJ, Lane MV, Merchenthaler IJ \& Frail DE 1998 Expression of growth differentiation factor-9 messenger ribonucleic acid in ovarian and nonovarian rodent and human tissues. Endocrinology 139 2571-2578.

Galloway SM, McNatty KP, Cambridge LM, Laitinen MPE, Juengel JL, Jokiranta S, McLaren RJ, Luiro K, Dodds KG, Montgomery GW, Beattie AE, Davis GH \& Ritvos O 2000 Mutations in an oocyte-derived growth factor gene (BMP15) cause increased ovulation rate and infertility in a dosage-sensitive manner. Nature Genetics 25 279-283.

Hanrahan JP, Gregan SM, Mulsant P, Mullen M, Davis GH, Powell R \& Galloway SM 2004 Mutations in the genes for oocyte-derived growth factors GDF9 and BMP15 are associated with both increased ovulation rate and sterility in Cambridge and Belclare sheep (Ovis aries). Biology of Reproduction 70 900-909.

Heldin C-H, Miyazono K \& ten Dyke P 1997 TGF $\beta$ signalling from cell membrane to nucleus through SMAD proteins. Nature 390 465-471.

Juengel JL, Hudson NL, Heath DA, Smith P, Reader KL, Lawrence SB, O'Connell AR, Laitinen MPE, Cranfield M, Groome NP, Ritvos O \& McNatty KP 2002 Growth differentiation factor 9 and bone morphogenetic protein 15 are essential for ovarian follicular development in sheep. Biology of Reproduction 67 $1777-1789$.

Juengel JL, Hudson NL, Whiting L \& McNatty KP 2003 Effects of immunization against bone morphogenetic protein 15 and growth differentiation factor 9 on ovulation rate, fertilization and pregnancy in ewes. Biology of Reproduction 70 557-561.
Kingsley DM 1994 The TGF- $\beta$ superfamily: new members, new receptors, and new genetic tests of function in different organisms. Genes and Development 8 133-146.

Kloos DU, Choi C \& Wingender E 2002 The TGF- $\beta$-Smad network: introducing bioinformatics tools. Trends in Genetics 18 96-102.

Knight PG \& Glister C 2003 Local roles of TGF- $\beta$ superfamily members in the control of ovarian follicular development. Animal Reproduction Science 78 165-183.

Laitinen M, Vuojolainen K, Jaatinen R, Ketola I, Aaltonen J, Lehtonen E, Heikinheimo M \& Ritvos O 1998 A novel growth differentiation factor-9 (GDF-9) related factor is co-expressed with GDF-9 in mouse oocytes during folliculogenesis. Mechanisms of Development 78 135-140.

Liao WX, Moore RK, Otsuka F \& Shimasaki S 2003 Effect of intracellular interactions on the processing and secretion of bone morphogenetic protein-15 (BMP-15) and growth and differentiation factor-9. Implication of the aberrant ovarian phenotype of BMP-15 mutant sheep. Journal of Biological Chemistry 278 $3713-3719$.

Liao WX, Moore RK \& Shimasaki S 2004 Functional and molecular characterization of naturally occurring mutations in the oocytesecreted factors BMP-15 and GDF-9. Journal of Biological Chemistry 271 17391-17396.

Lin S-Y, Morrison JR, Phillips DJ \& de Kretser DM 2003 Regulation of ovarian function by the TGF- $\beta$ superfamily and follistatin. Reproduction 126 133-148.

Mandon-Pepin B, Oustry-Vaiman A, Vigier B, Piumi F, Cribiu E \& Cotinot C 2003 Expression profiles and chromosomal localization of genes controlling meiosis and follicular development in the sheep ovary. Biology of Reproduction 68 985-995.

Mazerbourg S, Klein C, Roh J, Kaivo-Oja N, Mottershead DG, Korchynskyi O, Ritvos O \& Hsueh AJ 2004 Growth differentiation factor-9 (GDF-9) signalling is mediated by the type 1 receptor ALK5. Molecular Endocrinology 18 653-665.

McNatty KP, Juengel JL, Wilson T, Galloway SM, Davis GH, Hudson NL, Moeller CL, Cranfield M, Reader KL, Laitinen MPE, Groome NP, Sawyer HR \& Ritvos O 2003 Oocyte-derived growth factors and ovulation rate in sheep. Reproduction Supplement $\mathbf{6 1}$ 339-351.

McPherron AC \& Lee SJ 1993 GDF-3 and GDF-9: two new members of the transforming growth factor beta superfamily containing a novel pattern of cysteines. Journal of Biological Chemistry 268 3444-3449.

Miyazono K 2000 TGF- $\beta$ signalling by Smad proteins. Cytokine and Growth Factor Reviews 11 15-22.

Moore RK, Otsuka F \& Shimasaki S 2003 Molecular basis of bone morphogenetic protein-15 signaling in granulosa cells. Journal of Biological Chemistry 278 304-310.

Otsuka F \& Shimasaki S 2002 A novel function of bone morphogenetic protein-15 in the pituitary: selective synthesis and secretion of FSH by gonadotropes. Endocrinology 143 4938-4941.

Otsuka F, Yamamoto S, Erickson GF \& Shimasaki S 2001 Bone morphogenetic protein-15 inhibits follicle-stimulating hormone (FSH) action by suppressing FSH receptor expression. Journal of Biological Chemistry 276 11387-11392.

Richards J 2001 Perspective: the ovarian follicle - a perspective in 2001. Endocrinology 142 2184-2193.

Sadighi M, Bodensteiner KJ, Beattie AE \& Galloway SM 2002 Genetic mapping of ovine growth differentiation factor 9 (GDF9) to sheep chromosome 5. Animal Genetics 33 244-245.

Shackell GH, Hudson NL, Heath DA, Lun S, Shaw L, Condell L, Blay LR \& McNatty KP 1993 Plasma gonadotropin concentrations and ovarian characteristics in Inverdale ewes that are heterozygous for a major gene $\left(\mathrm{Fec} \mathrm{X}^{\mathrm{I}}\right)$ on the $\mathrm{x}$ chromosome that influences ovulation rate. Biology of Reproduction 48 1150-1156.

Shimasaki S, Moore RK, Otsuka F \& Erickson GF 2004 The bone morphogenetic protein system in mammalian reproduction. Endocrine Reviews 25 72-101. 
Sidis Y, Fukiwara T, Leykin L, Isaacson K, Toth T \& Schneyer AL 1998 Characterization of inhibin/activin subunit, activin receptor, and follistatin messenger ribonucleic acid in human and mouse oocytes: evidence for activin's paracrine signalling from granulosa cells to oocytes. Biology of Reproduction 59 807-812.

Souza CJ, Campbell BK, McNeilly AS \& Baird DT 2002 Effect of bone morphogenetic protein 2 (BMP2) on oestradiol and inhibin A production by sheep granulosa cells, and localization of BMP receptors in the ovary by immunohistochemistry. Reproduction $123363-369$.

Vitt UA, Hayashi M, Klein C \& Hsueh AJW 2000 Growth differentiation factor-9 stimulates proliferation but suppresses the follicle-stimulating hormone-induced differentiation of cultured granulosa cells from small antral and preovulatory rat follicles. Biology of Reproduction 62 370-377.
Vitt UA, Klein C \& Hseuh AJ 2002 Bone morphogenetic protein receptor type II is a receptor for growth differentiation factor-9. Biology of Reproduction 67 473-480.

Wilson T, Wu XY, Juengel JL, Ross IK, Lumsden JM, Lord EA, Dodds KG, Walling GA, McEwan JC, $\mathrm{O}^{\prime}$ Connell AR, McNatty KP \& Montgomery GW 2001 Highly prolific Booroola sheep have a mutation in the intracellular kinase domain of bone morphogenetic protein IB receptor (ALK-6) that is expressed in both oocytes and granulosa cells. Biology of Reproduction 64 1225-1235.

Yan C, Wang P, DeMayo J, DeMayo FJ, Elvin JA, Carino C, Prasad SV, Skinner SS, Dunbar BS, Dube JL, Celeste AJ \& Matzuk MM 2001 Synergistic roles of bone morphogenetic protein 15 and growth differentiation factor 9 in ovarian function. Molecular Endocrinology 15 854-866. 